\title{
Alpine bullhead (Cottus poecilopus Heckel): a potential refuge for Gyrodactylus salaris Malmberg, 1957 (Monogenea)
}

\author{
Tor A. Bakke ${ }^{1 *}$, Rachel A. Paterson ${ }^{2,3}$ and Jo Cable ${ }^{2}$ \\ ${ }^{1}$ Natural History Museum, University of Oslo, Department of Research and Collections, Oslo, Norway; \\ ${ }^{2}$ School of Biosciences, Cardiff University, Cardiff, United Kingdo \\ ${ }^{3}$ The Norwegian Institute for Nature Research, Trondheim, Norway
}

\begin{abstract}
The notifiable freshwater pathogen Gyrodactylus salaris Malmberg, 1957 tends to be a generalist in contrast to other monogeneans. Whilst it causes most damage to its primary host, the Atlantic salmon (Salmo salar Linnaeus), transport and reservoir hosts likely play a key role in maintaining the parasite in the environment. Here, we tested the ability of G. salaris (strain River Lierelva, southern Norway) to infect and reproduce on a population of wild caught alpine bullhead (Cottus poecilopus Heckel). Exposure of alpine bullhead yearlings $(0+)$ to $G$. salaris for $24 \mathrm{~h}$ at low $\left(6.5^{\circ} \mathrm{C}\right)$ or high temperature $\left(11.5^{\circ} \mathrm{C}\right)$ resulted in the establishment of 1 to 104 parasites per fish. Eight to nine days post-infection at high temperature, the infection of $G$. salaris was eliminated, indicative of innate host immunity. In contrast, at low temperature G. salaris infections persisted for 47-48 days. The relative lengthy infection of alpine bullhead with $G$. salaris compared to other non-salmonids tested may be due to low temperature and high initial infection load in combination with an epibiont infection. The present results suggest that this non-salmonid may function as a temperature-dependent transport or reservoir host for G. salaris.
\end{abstract}

Keywords: Gyrodactylidae, Siberian bullhead, Atlantic salmon, reservoir host, experimental infection, Norway

Successful establishment of invasive species in new regions is largely determined by the ability to find suitable resources to fulfill their habitat requirements (Torchin et al. 2003). For parasite species, invasion success is dependent on the presence of suitable hosts to maintain all life cycle stages, whether in the form of native species, or previously or co-introduced invasive hosts (i.e., parasite host switch; Bakke et al. 1992, 2002, Dunn 2009, Pettersen et al. 2016). In the case of parasites with direct life cycles such as monogeneans, invasion success is largely dependent on the presence of a suitable fish host (Bakke et al. 2007).

The invasive monogenean Gyrodactylus salaris Malmberg, 1957 was first detected in Norway in 1975 on a population of Atlantic salmon (Salmo salar Linnaeus) in Lakselva, Misvaer, Nordland County (Johnsen 1978). However, subsequent surveys revealed a widespread distribution of G. salaris (see Heggberget and Johnsen 1982, Bakke et al. 2007, Høgåsen et al. 2016). The invasive monogenean appeared highly pathogenic to the juvenile Atlantic salmon populations, with average losses of $86 \%$ (Johnsen et al. 1999).

Gyrodactylus salaris was also found to infect and reproduce on other salmonids, such as Arctic charr (Salvelinus alpinus [Linnaeus]), brook trout (Salvelinus fontinalis [Mitchill]), brown trout (Salmo trutta Linnaeus), rainbow trout (Oncorhynchus mykiss [Walbaum]), grayling (Thymallus thymallus [Linnaeus]), and salmon-brown trout hybrids (Bakke et al. 1992, 1999, 2002, Paladini et al. 2014). Amongst these alternative hosts, Arctic charr turned out to play a most significant role in the epidemics and dissemination of G. salaris (e.g., Bakke et al. 1996, Paladini et al. 2014).

Non-salmonid species may also have a role in the dissemination of $G$. salaris as transport or reservoir hosts (Bakke et al. 1992, 2002). However, in the eight non-salmonid species experimentally tested, namely three-spined stickleback (Gasterosteus aculeatus Linnaeus), ninespined stickleback (Pungitius pungitius [Linnaeus]), perch (Perca fluviatilis Linnaeus), roach (Rutilus rutilus [Linnaeus]), minnow (Phoxinus phoxinus [Linnaeus]), eel (Anguilla anguilla [Linnaeus]), flounder (Platichthys flesus [Linnaeus]), brook lamprey (Lampetra planeri [Bloch]), only a maximum infection for seven days (mean 4.1 days) was observed (reviewed by Bakke et al. 2007), similar to the maximum life span of G. salaris on dead salmonids (Olstad et al. 2006).

Temperature and climatic change may influence the dynamics between hosts and invasive monogeneans in freshwater ecosystems through various mediated mechanisms

\footnotetext{
*Address for correspondence: Tor A. Bakke, Natural History Museum, Postbox 1172 Blindern, 0318 Oslo, Norway. Phone +047 22851678; +047 95466130 E-mail: t.a.bakke@nhm.uio.no
} 


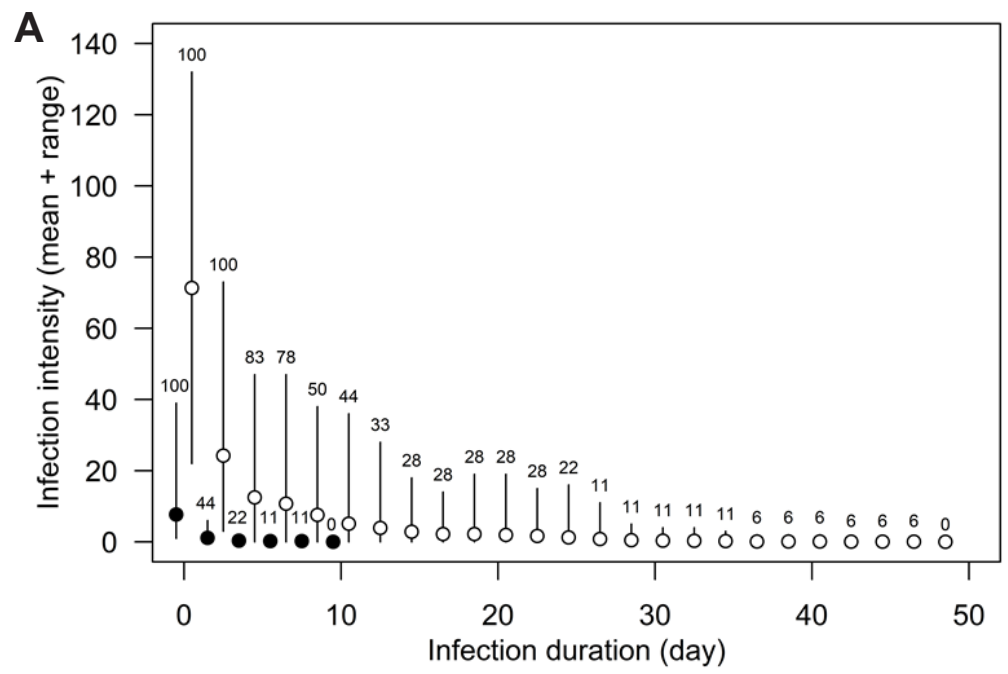

Fig. 1. Effect of temperature on infection with Gyrodactylus salaris Malmberg, 1957 on alpine bullhead, Cottus poecilopus Heckel, from the River Nitelva, southeastern Norway. A - mean infection intensity and duration; $\mathbf{B}$ - the relationship between initial infection load (Day 0) and infection duration. Open circles $=$ low temperature $\left(6.5 \pm 0.5^{\circ} \mathrm{C} ; \mathrm{n}=18\right)$; closed circles $=$ high temperature $(11.5 \pm$ $\left.0.3{ }^{\circ} \mathrm{C} ; \mathrm{n}=9\right)$; vertical bars and values $=$ range (minimum, maximum) and prevalence $(\%)$.

including reproduction and survival (e.g., Jansen and Bakke 1991, Bakke et al. 2007), transmission (Soleng et al. 1999, Marcogliese 2008) and infection seasonality (Jansen and Bakke 1993a, b). All of them are largely mediated by host immune responses (Sakai 1992, Muiswinkel and Der Wal 2006, Brooks and Hoberg 2007).

The fact that low environmental temperature can be immunosuppressive (Bly and Clem 1992) is suggestive of a thermal refuge for gyrodactylids poorly adapted to their hosts, allowing them to persist for sufficient time to further disseminate or allow genetic adaptation (Bakke et al. 2007). Gyrodactylus salaris, which is genetically highly variable throughout its range (Hansen et al. 2007, Mieszkowska et al. 2018), could also have been subject to substantial selection pressure based on host species or where it extends across different climatic zones (Dobson and Carper 1992, Olstad et al. 2007).

Gyrodactylids were previously recorded on $98 \%$ of alpine bullhead co-occurring with Atlantic salmon in Signaldalselva (Troms County, North Norway), at a mean intensity of 6.1 (Knudsen et al. 2004), although this probably represented a mixed infection of Gyrodactylus mariannae Winger, Hansen, Bachmann et Bakke, and G. salaris (see Winger et al. 2008). The lithophilous alpine bullhead, living in running water and also the littoral zone of lakes, has not previously been experimentally assessed for susceptibility to G. salaris (see Bakke et al. 2002). Hence, the current study assesses the ability of alpine bullhead to act as an alternative host for $G$. salaris under experimental conditions when subject to environmental stress based on temperature and a concurrent epizoic infection.

\section{MATERIAL AND METHODS}

\section{Host and parasite origin and maintenance}

Alpine bullhead (Cottus poecilopus) (ca. 50) young-of-theyear $(0+)$ were collected by electrofishing on 14 December 2001 from the River Nitelva $\left(60^{\circ} 13^{\prime} 47^{\prime \prime N}\right.$; 10 10 30'44"E), Oppland County, Norway and transported live to the Natural History $\mathrm{Mu}-$ seum's Aquarium Unit, University of Oslo. The status of infection with Gyrodactylus salaris was examined by screening all fish surfaces (fins, skin, mouth cavity, gills) from a random subsample of ten alpine bullhead euthanised by a blow to their head. No infection with Gyrodactylus spp. was detected. This is consistent with the alpine bullhead $(n=87)$ surveyed in $2002 / 2003$ from the same river (Winger et al. 2008). Prior to the experiment, alpine bullhead were maintained under continuous dim illumination at $11 \pm 0.5^{\circ} \mathrm{C}$ in one grey, plastic tank $(100 \times 100 \mathrm{~cm}, 30 \mathrm{~cm}$ water depth) supplied with charcoal-filtered, dechlorinated tap water and fed with unmedicated pellet food (Ewos Cermaq ASA, Oslo, Norway) ad libitum.

The strain of $G$. salaris (haplotype F; Hansen et al. 2003) was obtained from infected Atlantic salmon parr caught by electrofishing in Glitra, a tributary of the River Lierelva, Buskerud County $\left(59^{\circ} 50^{\prime} 3^{\prime \prime} \mathrm{N} ; 10^{\circ} 14^{\prime} 49^{\prime \prime} \mathrm{E}\right)$. This strain of G. salaris was thereafter transferred to a laboratory stock of naïve River Lierelva salmon parr exposed to infected salmon fins to increase the average infection level of $G$. salaris before the start of the experiments.

\section{Experimental design}

Twenty-seven naive alpine bullhead were randomly assigned to two temperature treatments $\left(6.5 \pm 0.5^{\circ} \mathrm{C}\right.$ and $\left.11.5 \pm 0.3^{\circ} \mathrm{C}\right)$ and acclimatised to these conditions under continuous dim illumination seven days before the infections. Due to space restrictions, the experiments were conducted over two time periods (low temperature: 27 February - 16 April; high temperature: 24 April 4 May); all laboratory conditions except for water temperature were kept constant. Each alpine bullhead was measured (average with range in parentheses: fork length, FL, mm; weight, $\mathrm{W}, \mathrm{g}$ ) at the start of the experiments low temperature $(\mathrm{n}=18)$ : FL 42.1 (34-47), W $0.68(0.33-0.99)$; high temperature $(n=9)$ : FL 44.4 (42-50), W 0.70 (0.60-0.95).

The infections with $G$. salaris were established by exposing alpine bullhead to fins of a heavily $G$. salaris infected salmon 


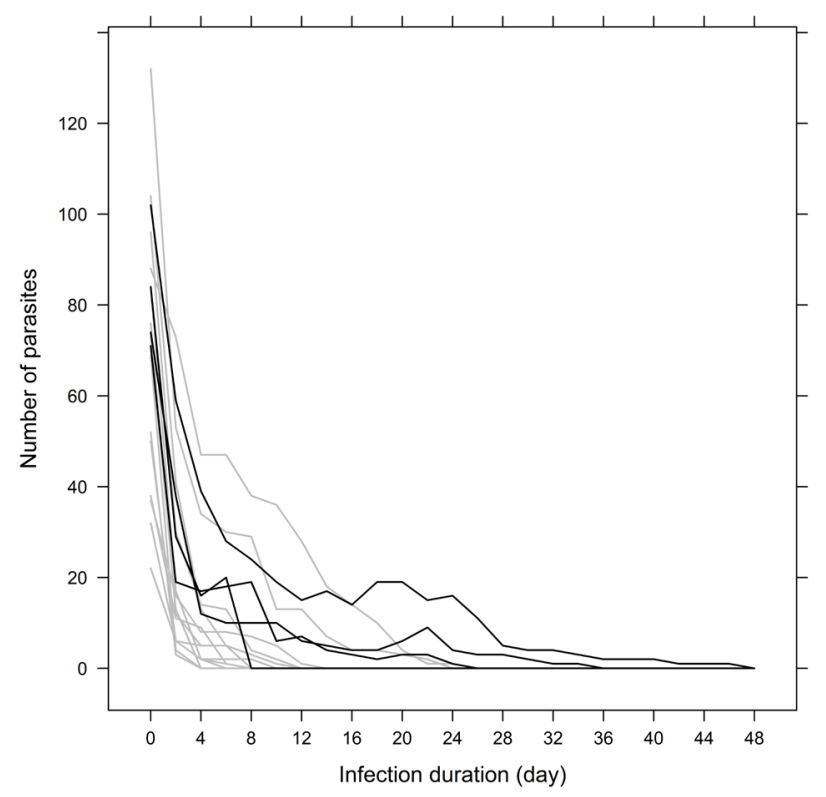

Fig. 2. Course of infection of Gyrodactylus salaris Malmberg, 1957 on individually isolated alpine bullhead, Cottus poecilopus Heckel, from the River Nitelva, southeastern Norway at low temperature $\left(6.5 \pm 0.5^{\circ} \mathrm{C} ; \mathrm{n}=18\right)$. The individual trajectories demonstrate that all fish were initially resistant but after a week individual variations was apparent. Black lines indicate individual fish where parasite reproduction may have occurred. The parasite was eliminated on the alpine bullheads after $47-48$ days.

(killed by a blow to its head) in plastic boxes $(37 \times 28 \mathrm{~cm}, 8 \mathrm{~cm}$ water depth) for 24 hours at the two temperatures. The alpine bullhead were then individually isolated into one of three compartments in floating plastic boxes (bottom wire mesh $5 \times 5 \mathrm{~mm}$ ) placed in a grey, plastic tank $(100 \times 100 \mathrm{~cm}, 30 \mathrm{~cm}$ water depth $)$. Gyrodactylus transmission between the compartments has previously never been observed in numerous similar experiments over two decades (see Bakke et al. 2002).

Changes in infections with G. salaris on the skin, fins and mouth cavity over time were quantified by use of a dissecting microscope every second day post-exposure by anaesthetising each bullhead in a $0.04 \%$ chlorobutanol (trichloro-2-methyl-2propanol) solution immediately prior to examination in accordance with previous experiments at different temperatures on non-salmonids (Jansen and Bakke 1991, Bakke et al. 2002). The gill arches were not examined to avoid physical damage to live fish. Each alpine bullhead was kept in their respective compartments until no infection with $G$. salaris was detected following two examinations. No fish mortality occurred. At low temperature, a co-occurring infection with epibionts (peritrichid ciliates) became apparent when the experiments started but was not quantified.

\section{Statistical analyses}

All analyses were conducted in R version 3.4.2 (R Development Core Team 2017). The effect of temperature on the duration of infection with $G$. salaris on alpine bullhead was examined using a generalised linear model (GLM) fitted with a quasipoisson distribution to account for over-dispersed count data. Preliminary data exploration indicated that mean infection intensity at Day 0 differed between temperature treatments. Therefore, infection intensity at Day 0 and fork length were included as covariates in our model, with both continuous measures scaled and centered on the mean before analysis.

\section{RESULTS}

Initial infection differed between the temperature treatments $\left(\mathrm{GLM}_{\mathrm{TEMP}}: F_{1,25}=46.16, p<0.001\right)$, with alpine bullhead acquiring on average 71.3 and 7.7 specimens of Gyrodactylus salaris at low and high temperatures, respectively (Fig. 1A). Fish in both temperature treatments demonstrated a general pattern of declining infection intensity and prevalence with time (Fig. 1B). A dramatic decline in parasite numbers occurred in the first two days post-infection in both treatment groups, but thereafter the decline levelled out. Maximum duration of infection differed between the temperature treatments $\left(\mathrm{GLM}_{\text {TEMP }}: F_{1,25}\right.$ $=12.39, p=0.002: 47-48$ and 8-9 days for low and high temperature, respectively) and was also influenced by the initial infection $\left(\mathrm{GLM}_{\mathrm{DAY}_{0} 0}: F_{1,26}=4.67, p=0.044\right.$; Fig. 1B). At low temperature, one fish still harboured 15 parasites at Day 21, but no parasites remained by Day 48 (Fig. 2). At high temperature only one fish remained infected at Day 7 and even this fish had lost all parasites by Day 8-9. The heaviest infected fish (39 G. salaris) at high temperature had eliminated the infection between Day 3 and 4 post-infection.

The overall parasite burden also declined on the low temperature fish, but there was evidence of an increased intensity of infection on four alpine bullheads (increasing from 4 to 9,14 to 19,17 to 19 and from 16 to 20) (Fig. 2).

\section{DISCUSSION}

The maximum duration of infection with Gyrodactylus salaris recorded on alpine bullhead in this study represents the longest continuous infection with this monogenean observed on a non-salmonid host. Previous studies suggested maximum persistence of one week on other non-salmonid species (Bakke et al. 2002). Jansen and Bakke (1991) experimentally observed a negative relationship between water temperature and the maximum lifespan of individual $G$. salaris on salmon parr, increasing from 8 days at $19^{\circ} \mathrm{C}$ to a peak of 58 days at $6.5^{\circ} \mathrm{C}$, with the life span declining when approaching $0^{\circ} \mathrm{C}$.

Whilst the maximum lifespan of 48 days on alpine bullhead at $6.5^{\circ} \mathrm{C}$ observed in the current study is less than the lifespan on salmon parr, it is significantly greater than that observed on any non-salmonid host. This prolonged infection on alpine bullhead may be due to the persistence of an individual parasite on the skin, migration from potentially infected gills, or even parasite reproduction at this temperature. If the latter, even though G. salaris is known to have a wider host range than most other gyrodactylids (Bakke et al. 1992, 2002), this study represents the first crossing of the parasite-host family border: salmonid to non-salmonid, providing an increased opportunity for speciation (Ziętara and Lumme 2002).

Alpine bullhead share the same microenvironment (shelter between gravel and stones, depth and river velocity) as 
salmon fry and parr, resulting in competition for both space and food. In fact, alpine bullhead may be the dominant of these two species, especially in high density populations (Gabler and Amundsen 1999, Svenning 2000) as also observed for Cottus gobio Linnaeus (see Gabler et al. 2001). The sympatry and niche overlap with salmon provides ideal conditions for $G$. salaris transmission and host switching (see Bakke et al. 2007).

In accordance with previous studies on other non-salmonid species experimentally infected with the haplotype $\mathrm{F}$ of $G$. salaris, once infected the population of G. salaris on alpine bullhead declined to elimination. The maximum average life span of individual $G$. salaris when feeding on its natural salmon host, or indeed when detached from a host, is negatively correlated with water temperature (Olstad et al. 2006). Environmental temperature not only impacts survival but also affects most other gyrodactylid functions (e.g., Gelnar 1991, Mohammed et al. 2016) and in the host both the alternative and classical complement pathway activities can be depressed during cold periods (Hayman et al. 1992, Collazos et al. 1994, Harris et al. 1998). In northern parts of Norway, river temperature is around $0^{\circ} \mathrm{C}$ during winter (see The Norwegian Water Resources and Energy: Directorate; https://www2.nve.no/h/hd/plotreal/WT/index.html). Such low temperatures may provide a refuge on non-salmonid hosts for $G$. salaris normally poorly adapted to these fish.

The two related sessile peritrich species, Vorticella sp. and Epistylis sp., which were observed in the current study attached by their stalks to the alpine bullhead skin at low temperature, are common ectocommensals on bottom dwelling fish and potential stressors. In general, fish ciliates tend to be pathogenic causing losses under aquaculture conditions (Lom and Dyková 1992) and red-sore disease epizootics caused by Epistylis sp. are considered to be most common during winter and spring months (Rogers 1971). Stress-induced immunosuppression of salmonids leading to increased susceptibility has previously been reported in salmonids (Buchmann 1997, Harris et al. 2000). The low temperature, the epibionts and lack of feeding during the experiment may all represent stressors, potentially interacting and negatively influenced alpine bullhead resistance to G. salaris.

In conclusion, we show that the alpine bullhead population (River Nitelva) may function as a transport host and even as a potential reservoir host for G. salaris (haplotype F) dependent on the ambient water temperature and environmental stressors.

Acknowledgements. This work was conducted at the Research Animal Department for Freshwater Fish (no. 166) at the Natural History Museum (NHM), University of Oslo. We thank Ann-Helén Rønning for technical assistance. This study was funded by the NRC Wild Salmon Program (project no. 145861/720), the National Centre for Biosystematics (project no. 146515/420) and the European Union's Horizon 2020 research and innovation program under the Marie Skłodowska-Curie grant agreement (Project no. 663830).

R.L Peters and T.E. Lovejoy (Eds), Global Warming and Biodiversity. Yale University Press, New Haven, pp. 201-207.

Dunn A.M. 2009: Parasites and biological invasions. Adv. Parasitol. 68: 161-184.

Gabler H.M., Amundsen P.A. 1999: Resource partitioning between Siberian sculpin (Cottus poecilopus Heckel) and Atlantic salmon parr (Salmo salar L.) in a sub-Arctic river, northern Norway. Ecol. Freshw. Fish 8: 201-208.

Gabler H.M., Amundsen P.A., Herfindal T. 2001: Diet segregation between introduced bullhead (Cottus gobio L.) and Atlantic salmon parr (Salmo salar L.) in a sub-Arctic river. Arch. Hydrobiol. 151: 609-625.

Gelnar M. 1991: Experimental verification of the effect of constant and changing water temperature on the micropopulation growth in Gyrodactylus gobiensis Gläser, 1974 (Monogenea) parasitizing gudgeon (Gobio gobio L.). Folia Parasitol. 38: 123-131.

Hansen H., Bachmann L., Bakke, T.A. 2003: Mitochondrial DNA variation of Gyrodactylus spp. (Monogenea, Gyrodactylidae) populations infecting Atlantic salmon, grayling and rainbow trout in Norway and Sweden. Int. J. Parasitol. 33: 1471-1478.

Hansen H., Bakke T.A., Bachmann L. 2007: DNA taxonomy and barcoding of monogenean parasites: lesson from Gyrodactylus. Trends Parasitol. 23: 363-367.

Harris P.D., Soleng A., Bakke T.A. 1998: Killing of Gyrodactylus salaris (Platyhelminthes, Monogenea) mediated by host complement. Parasitology 117: 137-143.

Harris P.D., Soleng A., BaKke T.A. 2000: Increased susceptibility of salmonids to the monogenean Gyrodactylus salaris following administration of hydrocortisone acetate. Parasitology 120: $57-64$.

Dobson A., CARPER R. 1992: Global warming and potential changes in host-parasite and disease-vector relationships. In: 
Hayman J.R., Bly J.E., Levine R.P., LobB C.J. 1992: Complement deficiencies in channel catfish (Ictalurus punctatus) associated with temperature and seasonal mortality. Fish Shellfish Immunol. 2: 183-192.

Heggberget T.G., Johnsen B.O. 1982: Infestations by Gyrodactylus sp. of Atlantic salmon, Salmo salar L., in Norwegian rivers. J. Fish. Biol. 21: 15-26.

Høg̊̊sen H.R., Hytterød S., Aune S., Adolfsen P. 2016: [The hazard of invasion of Gyrodactylus salaris to Norwegian rivers in Troms and Finnmark from border areas in Russia, Finland and Sweden.] Veterinærinstituttets Rapportserie, Endelig rapport, Rapport 1: 1-84. (In Norwegian.)

JANSEN P.A., BAKKe T.A. 1991: Temperature-dependent reproduction and survival of Gyrodactylus salaris Malmberg, 1957 (Platyhelminthes: Monogenea) on the Atlantic salmon (Salmo salar L.). Parasitology 102: 105-112.

JANSEN P.A., BAKKe T.A. 1993a: Regulatory processes in the monogenean Gyrodactylus salaris Malmberg - Atlantic salmon (Salmo salar L.) association: I. Field studies in south-east Norway. Fish. Res. 17: 87-101.

JANSEN P.A., BAKKe T.A. 1993b: Regulatory processes in the monogenean Gyrodactylus salaris Malmberg - Atlantic salmon (Salmo salar L.) association: II. Experimental studies. Fish. Res. 17: 103-114.

JoHnsen B.O. 1978: The effect of an attack by the parasite Gyrodactylus salaris on the population of salmon parr in the river Lakselva, Misvaer in northern Norway. J. Arctic Biol. 11: 7-9.

Johnsen B.O., Møkkelgjerd P.I., Jensen A.J. 1999: [The parasite Gyrodactylus salaris on salmon parr in Norwegian rivers, status report at the beginning of year 2000.] NINA Oppdragsmelding 617: 1-129. (In Norwegian, with English abstract.)

Knudsen R., Rikardsen A., Kristoffersen R., Sandring S., Sikavoupio S. 2004: [Registration of Gyrodactylus spp. in the fish community of Signaldalselva and Kitdalselva in Troms 2003.] NINA Oppdragsmelding 817: 1-24. (In Norwegian, with English summary.)

Lom J., Dykoví I. 1992: Protozoan Parasites of Fishes. Developments in Aquaculture and Fisheries Science 26. Elsevier, Amsterdam. 315 pp.

Marcogliese D.J. 2008: The impact of climate change on the parasites and infectious diseases of aquatic animals. Rev. Sci. Tech. 27: 467-484

Mieszkowska A., Górniak M., Jurczak-Kurek A., Ziętara M.S. 2018: Revision of Gyrodactylus salaris phylogeny inspired by new evidence for Eemian crossing between lineages living on grayling in Baltic and White sea basins. Peer J. 6: e5167.

Mohammed R.S., James J., Reynolds M., Williams C., van Oosterhout C., Mohammed A., Ramsubhag A., Cable J.
2016: Getting into hot water: sick guppies frequent warmer thermal conditions. Oecologia 181: 911-917.

Muiswinkel W.B., Der Wal B.V.V. 2006: The immune system of fish. In: P.T.K. Woo (Ed.), Fish Diseases and Disorders. Second edition. CAB International, Wallingford, pp. 678-701.

Olstad K., Cable J., Robertsen G., Bakke T.A. 2006: Unpredicted transmission strategy of Gyrodactylus salaris (Monogenea: Gyrodactylidae): survival and infectivity of parasites on dead hosts. Parasitology 133: 33-41.

Olstad K., Robertsen G., Bachmann L., Bakke T.A. 2007: Variation in host preference within Gyrodactylus salaris (Monogenea): an experimental approach. Parasitology 134: 589-597.

Paladini G., Hansen H., Williams C.F., Taylor N.G.H., RuBio-Mejía O.L., Denholm S.J., Hytterød S., Bron J.E., SHINN A.P. 2014: Reservoir hosts for Gyrodactylus salaris may play a more significant role in epidemics than previously thought. Parasit. Vectors 7: 576.

Pettersen R.A., Østbye K., Holmen J., Vøllestad L.A., Mo T.A. 2016: Gyrodactylus spp. diversity in native and introduced minnow (Phoxinus phoxinus) populations: no support for "the enemy release" hypothesis. Parasit. Vectors 9: 51.

R Core Team 2017: R: A Language and Environment for Statistical Computing. R Foundation for Statistical Computing. Vienna, Austria.

Rogers W.A. 1971: Diseases in fish due to the protozoan Epistylis (Ciliata: Peritricha) in the southeastern U.S. Proceedings of the Southeastern Association of Game Fish Commisioners, 25th Annual Conference, Charleston, 493-496.

SAKAI D.K. 1992: Repertoire of complement in immunological defense mechanisms of fish. Ann. Rev. Fish Dis. 2: 223-247.

Soleng A., JAnsen P.A., BAKke T.A. 1999: Transmission of the monogenean Gyrodactylus salaris. Folia Parasitol. 46: 179-184.

Torchin M.E., Lafferty K.D., Dobson A.P., McKenzie V.J., KURIS A.M. 2003: Introduced species and their missing parasites. Nature 421: 628-630.

Svenning M.-A. 2000: [Densities of juvenile salmon (Salmo salar) and sculpin (Cottus poecilopus) in the Reisa river, Troms.] NINA Oppdragmelding 663: 1-16. (In Norwegian, with English abstract.)

Winger A.C., Hansen H., Bachmann L., Bakke T.A. 2008 : Gyrodactylus species (Monogenea) infecting alpine bullhead (Cottus poecilopus Heckel, 1837) in Norway and Slovakia, including the description of Gyrodactylus mariannae sp. nov. Acta Parasitol. 53: 240-250.

Ziętara M.S., Lumme J. 2002: Speciation by host switch and adaptive radiation in a fish parasite genus Gyrodactylus (Monogenea, Gyrodactylidae). Evolution 56: 2445-2458.

Cite this article as: Bakke T.A., Paterson R.A., Cable J. 2019: Alpine bullhead (Cottus poecilopus Heckel): a potential refuge for Gyrodactylus salaris Malmberg, 1957 (Monogenea). Folia Parasitol. 66: 018. 